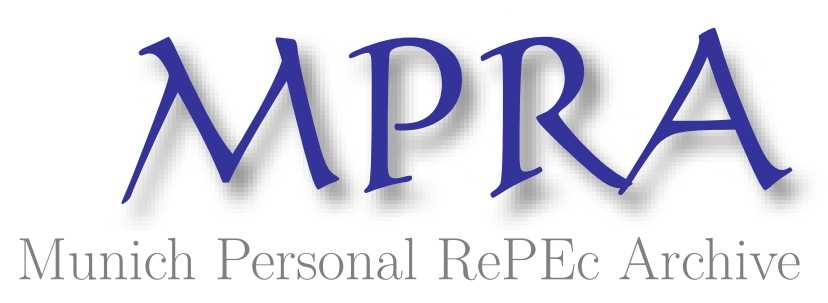

\title{
Marx without Equilibrium
}

Freeman, Alan

The University of Greenwich

July 1995

Online at https://mpra.ub.uni-muenchen.de/1207/

MPRA Paper No. 1207, posted 18 Dec 2006 UTC 


\section{Marx without equilibrium}

\section{INTRODUCTION}

For ninety of the hundred years since the third volume of Capital was published in October 1894, a single representation of its contents has been accepted by the academic world. Its core is the idea that values and prices are given by the solution to two independent systems of simultaneous equations. It has convinced three generations of theorists that Marx's key conclusions are either wrong or incompatible.

Its vertebral column is an assertion that, until recently, almost no-one has questioned: since inputs are bought at prices different from their values, these prices must be the same as those of the outputs they are used to produce. Introduced by Ladislaw von Bortkiewicz in three keynote articles published between 1906 and 1907, this 'correction' is logically and factually untenable. Inputs are not purchased at the prices of their own outputs, but at those of a previous period, in general different from the prices of the current period. The correction imposes a logical requirement which is incompatible with chronological time.

This skeleton is cloaked in simplifying assumptions which ninety years of scholarship have never dispensed with, because they are really disguised postulates, imposed by the use of the simultaneous method: the profit rate is everywhere actually equal, technology does not change, the market always clears during each act of circulation, and money is a pure numéraire.

These ground rules belong to the school of thought founded by Marie-Esprit Léon Walras and now known as General Competitive Equilibrium. They are apologetic, logically incoherent and unrealistic. Their net effect is to eradicate capital - self-expanding value. Value theory has been assimilated to an alien body of thought.

An emerging non-equilibrium alternative not only shows Marx's contested conclusions to be precisely true, but offers a clear and coherent explanation of the most puzzling observed phenomena of market economies today including the falling rate of profit, the business cycle, and why technical progress coexists with mass poverty and growing inequality. This article aims to introduces this alternative to the non-mathematical reader.

\section{Foundations of the alternative: sequential and nondualistic approaches}

The break with the Bortkiewicz tradition arises from two sources we term sequential and nondualistic. Sequentialists seek to restore chronological time, while nondualists reassert Marx's codetermination of values and prices.

The sequential view originates in the neglected tradition of 'iterative' solutions to the transformation problem. The first, almost ignored in the literature, was Shibata's. Since then Okishio (1972), Shaikh (1977), Morishima and Catephores, Panizza, and Pala have rediscovered or developed the idea of transformation as a sequence of intermediate prices converging - if technology does not change - on the simultaneous solution, the input prices for each step being the output prices of the previous step. However for these authors, who reject nondualistic conclusions, such intermediate prices have no objective historical actuality: they are an ideal construction en route to the 'real' simultaneous prices, a form of Marxist tatônnement.

Nondualists, including Wolff, Callari and Roberts, Moseley, and Rodriguez and Ramos, work with simultaneous, equal-profit-rate systems but replace Bortkiewicz's two independent systems with a single set of equations linking prices and values. By reasserting the key conceptual status of money and of circulation in the formation of value, they can illustrate Marx's own position that the value transferred to outputs by consumed inputs is the exchange value of the money paid for these inputs, 
not the value of the inputs themselves. Equally, the value appropriated by workers is the exchange value of the money paid for consumed variable capital. ${ }^{1}$

A growing minority - Langston, Carchedi, Freeman, Andrews, Naples, Kliman and McGlone, and Giussani - unites these two insights, dispensing entirely with the mainstream synthesis. I believe this to be essential, and a secondary aim of this article is to persuade the nondualists to become sequentialists and the sequentialists to become nondualists. ${ }^{2}$

Neither insight makes sense without the other. The nondualists restore Marx's conception that values emerging from production are transformed in circulation, and that the resultant prices form the basis for new values in production. But these changes follow one another in time; prices are not the basis of the same set of values as before but a new and later set. Divorced from this fact, the argument either appears as an obscure philosophical diatribe or branches off into the radically false idea that money is the sole measure of value. Writers in the iterative tradition, however, cannot explain the real chronological process which incorporates dead labour in a commodity because they do not accept that this dead labour passes into the value of a product in the form of the money paid for it.

The combination of the two insights amounts to a complete paradigm shift. Without the comforting but illusory bedrock of simultaneous determination, the most basic concepts of economic analysis must be deduced and presented dynamically, stripped of the presupposition that the market clears, or that prices and technology remain obligingly constant. The necessary radical difference in logical method dispenses with all conventional 'simplifications'. It provides a rigorous foundation for explaining technological change in a money economy.

More is therefore at stake than a retrospective correction. A growing body of pathbreaking new work - for example on capitalist dynamics, on money, trade, and the theory of demand - testifies to the vitality of this emerging view and shows that entirely new ground can be broken by dispensing with Bortkiewiczian assumptions. ${ }^{3}$ When value theory is reformulated on non-equilibrium lines, above all when fixed capital is integrated, the result is a comprehensive and rigorous alternative to neoclassical economics in all its variants. One hundred years on, we can represent precisely and logically what Marx set out to do.

\section{THE ROOTS OF EQUILIBRIUM MARXISM}

Bortkiewicz did not reformulate Marx in a vacuum. In 1887, then nineteen, he opened a lifelong correspondence with Walras, whom he regarded as his mentor, with the following words (Jaffé 1965 Vol II:230)

Your writings, sir, have awakened in me a lively interest in the application of mathematics to political economy, and has pointed out to me the road to travel in my researches into the methodology of economic science.

Within three years of Volume III's appearance the now-familiar accusation that Marx failed to 'transform inputs' was first levelled by the anti-Marxist Komorzynsky in Böhm-Bawerk's Zeitschrift für Volkswirtschaft, Socialpolitik und Verwaltung. Dmitriev's (1905) contribution, the progenitor of Bortkiewicz's, was actually entitled An outline of an organic synthesis of the labour theory of value and the theory of marginal utility. These contributions were all part of an intensive thirty-year effort which founded the new school of economic thought that became known as neoclassical economics. Marginalism was its public face - but its soul was the simultaneous method. The declared purpose of Bortkiewicz's contribution, in Max Weber and Werner Sombart's Archiv für Sozialwissenschaft und Sozialpolitik, was to assimilate Marx to the method of this new school.

Twentieth Century politics forged the new doctrine into a scourge for the Marxists; they obligingly applied it to their own backsides. They seized on the simultaneous method and counterposed it to marginalism, not recognizing that the two ideas were cut from the same cloth. Ridiculing their neighbours for wearing trousers without a jacket, they flaunted the jacket without the trousers.

To understand how a venture now portrayed as clash of irreconcilables began as a common enterprise, it must be recognised that the doctrine began life, like many orthodoxies, as a heterodoxy seeking recognition. Walras called himself an 'ethical socialist', the marginalists were mostly social critics and Tugan was a Legal Marxist. In the Germany of the anti-socialist laws, the Russia of Czarist 
censorship and the Austria of the Emperors there was a common need for a respectable social doctrine, conforming to the general culture of a radicalising intelligentsia but permitting legitimacy and academic promotion in a general atmosphere of persecution and conservatism. Walras's system fitted this purpose. A perfectly-formed apologetic system, the mathematical distillation of NineteenthCentury bourgeois wisdom, it justified rational social analysis by proving the market can achieve what the analysts prescribe. As we shall show, it proves it because it assumes it.

\section{The simultaneist concept of determination}

Bortkiewicz regarded Walras (see Gattei 1982) as the founder of a new, correct technique of price determination superseding and replacing Marx. From him he absorbed and consciously adopted a principle alien to Marx:

Alfred Marshall said once of Ricardo: 'He does not state clearly, and in some cases he perhaps did not fully and clearly perceive how, in the problem of normal value, the various elements govern one another mutually, not successively, in a long chain of causation.' This description applies even more to Marx...[who] held firmly to the view that the elements concerned must be regarded as a kind of causal chain, in which each link is determined, in its composition and its magnitude, only by the preceding links...Modern economics is beginning to free itself gradually from the successivist prejudice, the chief merit being due to the mathematical school led by Leon Walras. ${ }^{4}$

The view that prices at different times were determined simultaneously led to the approach that has since become standard: an equation system in which input and output prices are the same. This idea is the cornerstone of the twentieth century interpretation of Marx. Yet a little thought reveals it as impossible and absurd.

Bortkiewicz's assertion is this: that the capitalists buy today's inputs at tomorrow's prices. To do so they would either have to be clairvoyant or live in a perfectly planned economy. ${ }^{5}$ In fact what happens is this: they first buy their inputs, then produce their goods, and then sell them - at new and different prices.

The cost of Bortkiewicz's apparently minor adaptation is devastating. As we shall show, it purges the market of every actual source of variation. It eliminates trade at non-equilibrium prices, logically posits market clearing; relegates money to the status of a scaling factor, excises technical change and above all is hermetically sealed against the life-force of capitalist accumulation itself: the movement of capital. These well-known features of Walrasian General Equilibrium are logical consequences of any system of simultaneous equations and hence of the Twentieth-Century version of Marxism.

\section{The abolition of market prices and the suppression of money}

The ideological content of the simultaneist construction begins to emerge from its chrysalis when it is recognised, setting aside time travel, that there is only one logical way to make input prices equal to output prices, which is to constrain them not to change in the meantime - that is, to demand they are constant.

There is only one solution to a simultaneous system. Therefore, it cannot change. All equilibrium accounts relegate the 'process of adjustment', which requires prices to move until this solution is reached, to a shadowy virtual world which never intrudes on reality.

As a consequence, the process of economic change is now modelled by cartoonists. The stop-time animation called comparative statics is supposed to happen like this: at one point in time, there is a given 'technology' and a given real wage, giving unique prices and a unique equal profit rate. Then, at another point, there is a new wage and perhaps a new technology, giving new unique prices and a new unique profit rate. A rapid succession of these flickering images represents economic movement.

This befits the modern age but has little to do with science. The illusion of movement is introduced by recalculating prices from one period to another. Since these prices are different, they appear to have moved. But movement involves more than just difference; it also requires a process of transition. What has to be explained is how the market gets from one period to the other. Which prices do the capitalists pay? If they pay the old prices, then all periods are the same. But if they pay the new 
prices, then they buy their commodities at a price different from that at which they sell them. This is to say the least more problematic than Marx's transformation.

In the simultaneous framework, deviations from fixed-point prices are defined as accidents to be ignored or complications to explain later. But actual market prices, determined by the interplay of supply and demand, change all the time. Any analysis of a real market economy has to explain trade at disequilibrium prices because they are the only prices anyone actually uses. To start by assuming they do not exist is like studying a centipede by nailing it to the floor.

It is conventional to argue, following Sweezy, that the deviation of market prices from prices of production arises from 'successive approximations to reality.' Volume I analysed values; Volume III analysed prices of production, and Volume VI would have reached market prices. Values thus constitute the 'essence' of prices of production which in turn constitute the essence of market prices. According to this conception, the issue of money and market prices does not arise until the most concrete, least abstract level of analysis is reached.

The logical flaw in this convention is as follows: unless prices differ both from values and from prices of production, neither can even be formed. Marx (1935:56) made this the centre of his polemic with Proudhon as early as 1847:

it is the variations of supply and demand that show the producer what amount of a given commodity he must produce in order to receive in exchange at least the cost of production. And as these variations are continually occurring, there is also a continual movement of withdrawal and application of capital in the different branches of industry...If M. Proudhon admits that the value of products is determined by labour time, he should equally admit that it is the fluctuating movement alone that makes labour the measure of value. There is no ready-made constituted "proportional relation" but only a constituting movement.

Engels's introduction to the same work puts it even more strongly:

the continual deviation of the prices of commodities from their values is the necessary condition in and through which alone the value of the commodities can come into existence.

The same applies mutatis mutandis to prices of production. The prices for which commodities sell are neither values nor prices of production, not in Marx nor in the real world. They are market prices, constantly in motion, never actually equating supply to demand. But how can disequilibrium trading be discussed with a concept of price which assumes it impossible? This logical absurdity inserts itself into countless controversies and problems in the economics of the age: for example the Cambridge critique of the neoclassical production function; Harrod's razor edge, the lack of a solution to the equations of general equilibrium under increasing returns to scale, and so on and so on. The many interesting attempts by heterodox non-Marxist economics to escape the dead hand of equilibrium all founder on the lack of an adequate concept of value and price with which to discuss disequilibrium trading. ${ }^{6}$

Marx's concept of price in my view avoids all such circularity and is therefore vastly theoretically superior as the foundation of a non-equilibrium approach. It is developed, very carefully, in tandem with his analysis of money, in Volume I, before he discusses or requires social reproduction. It therefore does not depend on the assumption of reproduction and cannot be falsified if this assumption is dropped. It applies to general market prices.

Marx's market prices are not simply exchange ratios which circulate goods in pre-ordained proportions, as they were for Proudhon, Say, Walras and Sraffa. They are money prices, the rate of exchange for a distinct commodity whose specific use is to serve as a universal equivalent. Now, the exchange of commodities for money is what capitalism is. The elimination of market prices thus eliminates the differentia specifica of the capitalist mode of production. In simultaneous systems, money-price is replaced with a totally different concept: the rates of exchange necessary to achieve certain definite ratios of supply to demand, that is, ratios based on the prior assumption of market clearing. 


\section{The dead hand of Jean-Baptiste Say and the imposition of market clearing}

The use of simultaneist prices imposes an absolute limit on the study of disequilibrium (that is, actual) economic movement, manifested in the fact, as we have just shown, that they cannot represent the process by which prices change. An apparent temporary simplification is translated into a postulate, a logical prerequisite which can never be overcome.

Economics has regressed to a pre-Copernican stage, rooted in a preconceived theoretical perfection of the market. When practical economists such as Keynes and Schumpeter have to grasp the actual market, functioning quite independently of its divine Concept, they are driven to reintroduce what this concept has destroyed. They must re-invent money, theorise technical progress, account for disequilibrium trading and explain involuntary unemployment. This enterprise constantly founders because their analytical tools were forged by assuming away what they wish to study.

What other 'simplifications' required by the simultaneous solution have the same character? What else does the simultaneist construction necessarily presuppose or, as speculative philosophy puts it, what does it posit? When we survey the Twentieth Century and note that the same simplifications in 1905 are still with us in 1995, it is reasonable to ask why they have never been removed and to suggest that they never will be, at least not within the simultaneist framework. Most important of all is the assumption on which all apologetics rests and against which Marx inveighed throughout his writings: Say's Law or the assumption of market clearing.

'The inane Say', as Marx describes him, has posthumously donated his name to the following conception: because every sale is an exchange and hence a purchase, the total of all sales must equal the total of all purchases and it is impossible, therefore, to have a general surplus or a general shortage of all goods. This idea is so disruptive of any attempt to understand a real market economy that Keynes made it the basis of his classification of economics: classicals are those who support Say's law. As for Marx, he singles out 'this miserable individual' for more vitriol than any other contemporary except perhaps Malthus.

Say's Law is built into the simultaneist construction. The proof can be approached in one of two ways: by considering the role of money in such systems or by considering how prices regulate the interplay of supply and demand.

Marx's polemic begins from the fact that goods do not exchange for each other but for money. The hidden assumption in Say's law is the simultaneous satisfaction of wants; every commodity acquired in exchange is assumed to be used directly by the purchaser. In a money economy agents do not directly acquire what they need but 'purchase' a special commodity used only to purchase other commodities. This use does not destroy money which therefore functions as a stock, not as a flow. If, therefore, agents acquire money, a non-consumed use, then it is perfectly possible for them simply to hang on to it - as Marx puts it, purchase can be separated from sale.

In a simultaneous system, money does not appear, a well-known property that the Post-Keynesians particularly have criticised (see for example Clower). This is not an accident. Prices in a simultaneous system are defined to be those rates of exchange at which all agents will dispose of their outputs and consume their inputs. The destination of every good is its direct consumer; goods thus exchange not for money but for each other. Such systems in fact represent barter, in which a mismatch of supply to demand is possible only if the wrong prices rule.

Is there any way to escape this restriction of a simultaneous system? I would argue it is inherent, the logical dual of constant prices. Suppose there is a shortage or surplus of any good, however temporary. In the real world prices move away from their equilibrium and this rectifies the disturbance. But simultaneous prices by definition cannot move from their equilibrium. With constant prices, there is no mechanism to equate supply to demand; it must be presupposed.

This is recognised by Walras and Sraffa who both make it the foundation of their systems; prices are those which will perfectly distribute all outputs in the same proportions as the inputs which produced them. ${ }^{7}$ However it wreaks havoc with Marx's system, in which the determination of prices and values is the result of capital movement in pursuit of surplus profits. Why should capital migrate from one sphere to another if all processes yield an identical and eternally equal profit rate?

It has become conventional, because Twentieth Century Marxism has taken a stand against marginalism instead of the simultaneous method, that Marx abstracts from supply-demand differences throughout his work. It would be more accurate to say that General Equilibrium has a subjective concept of their effect on prices, whereas Marx (and Ricardo) have an objective concept in which 
such differences impact not just on the minds of the agents, but reality, as the necessary process by which values form as an average of constant deviations. Interpreters constantly forget that when Marx studies abstract equilibria these are the result of a presupposed disequilibrium and cannot be understood by eliminating this a priori:

In actual fact, supply and demand never coincide, or if they do so, it is only by chance and not to be taken into account for scientific purposes: it should be considered as not having happened. Why then does political economy assume that they do coincide? In order to treat the phenomena it deals with in their law-like form, the form that corresponds to their concept, i.e. to consider them independently of the appearance produced by the movement of demand and supply (CIII:291)

Disequilibrium is present from the outset, in order to make temporary abstraction from it. If it is defined as absent, it is not there to be abstracted from and it can never be put back. 'Appearance' here does not mean 'illusory' as three generations of Marxists have supposed but refers to its 'form of appearance'(Erscheinungsform), its concrete manifestation: that is, what actually happens. The 'illusion' is the price of production which so many Marxists perversely take for the true essence of price:

Between these spheres that approximate more or less to the social average, there is again a tendency to equalisation, which seeks the 'ideal' mean position, i.e. a mean position which does not exist in reality. (CIII p273)

Marx's is a disequilibrium economics from the start, in which prices and profits are in constant motion with constant discrepancies between supply and demand; simultaneous equation systems, which posit constant prices and market clearing, cannot form the basis of this economics - or indeed, of any economic science at all.

\section{THE CONTRADICTIONS OF EQUILIBRIUM MARXISM}

Bortkiewicz's construction was neither conceived as, nor is, an alternative to Walrasian economics; it just comes with a different story. Marxists have chosen to sink with his system while singing this story. As a result, Marx's own concepts have drowned. The simultaneous method determines the idea necessary to explain it. Marx's concepts have mutated to the point where readers cannot see what he actually wrote, and writers systematically attribute things to him which he simply did not say. ${ }^{8}$

History has exacted an ironic price; the contradictions and logical failings of the simultaneous system have been criticised far more rigorously in their Marxist than in their marginalist form, and their ultimate limits revealed earlier in this criticism. But the flightless fledglings of Walrasian economics, the logical contradictions to which it has given birth, have been fostered like a cuckoo on the Marxists. The working out of its internal contradictions has taken the distorted form of a ceaseless onslaught on Marx and his economics for faults whose origin lies in the theories of the critics. To paraphrase Hegel, the cunning of reason has given way to the neurosis of unreason. Scientific economy has to reconstruct the original concepts, not out of hagiographic reverence, but so that the evolution of reason can resume. ${ }^{9}$

\section{The transformation of the transformation problem}

Bortkiewicz's anti-successivism imposed a conception alien to Marx; that values and prices constituted two separately determined systems. ${ }^{10}$ The 'transformation problem' was completely restated. Marx's question was this: what is the relation between values and prices in the same economy at two points in time? Bortkiewicz's question was this: what is the relation between prices in two different economies at the same point in time? 
To this end he promulgated the idea that the value transferred to outputs by constant capital was equal to the value of the consumed means of production as distinct from its price. This appear nowhere in Marx's writings. In Theories of Surplus Value he writes:

$[\mathrm{T}]$ he cost price $^{11}$ of constant capital - or of the commodities which enter into the value of the newly-produced commodity as raw materials, auxiliary materials and machinery [or] labour conditions - may likewise be either above or below its value. Thus the commodity comprises a portion of the price which differs from value, and this portion is independent of the quantity of labour newly added, or the labour whereby these conditions of production with given cost-prices are transformed into a new product. ...the difference between cost-price and value, insofar as it enters the price of the new commodity independently of its own production process, is incorporated into the value of the new commodity as an antecedent element. (Marx 1969: 167, my emphasis - AF)

This is repeated in Volume III of Capital on p309, which adds:

The 20v [variable capital - AF] can similarly diverge from this value, if the spending of wages on consumption involves commodities whose prices of production are different from their values. The workers must work for a greater or lesser amount of time in order to buy back these commodities (to replace them) and must therefore perform more or less necessary labour than would be needed if the prices of production of their necessary means of subsistence did coincide with their values. [my emphasis - AF]

Thus consumed means of production transfer their price - the labour time represented by the money paid for them - to the product, and the workers appropriate the price of the goods bought with the wage, that is, the labour time needed 'to buy back these commodities'.

This is perfectly rational. The capitalists part with a sum of money with which they buy the inputs. Why should this transmit anything to the product other than the value of this money? Why should surplus value be anything other than the value of the product less the value of the money given to the workers?

Tradition claims Marx never explained how to transform inputs, leaving it as a 'difficult' problem for later solution. But it is already done in Volume I because all quantities are already given in money, a source of great puzzlement to his simultaneist interpreters. As Suzanne de Brunhoff (1976:27) points out, the price-value distinction is posed in part 1 of Volume I:

suppose two equal quantities of socially necessary labour are respectively represented by one quarter of wheat and $£ 2$ (approximately $1 / 2$ oz of gold). $£ 2$ is the expression in money of the magnitude of the value of the quarter of wheat, or its price. If circumstances now allow this price to be raised to $£ 3$, or compel it to be reduced to $£ 1$, then although $£ 1$ and $£ 3$ may be too small or too large properly to give proper expression to the magnitude of the wheat's value, they are nevertheless prices of the wheat, for they are, in the first place, the form of its value, i.e. money, and, in the second place, the exponents of its exchange-ratio with money...the possibility, therefore, of quantitative incongruity between price and magnitude of value, i.e. that the price may diverge from the magnitude of value, is inherent in the price-form itself. (CI:196)

So why does Marx not allow market prices to diverge from value from this point on? Because of the risk of a circular argument. The categories of labour process and surplus value have to be developed without assuming facts such as the formation of prices of production, which can only be proved once these categories have been developed. Marx's logical method, located in the tradition of speculative philosophy, is to develop each concept without presupposing its enrichment by what is yet to be derived from it, ${ }^{12}$ at the same time ensuring it could not be falsified by this subsequent enrichment when it is due. This is the much-mystified process of reflection-determination.

Consider for example the following statement from Volume I: 
Suppose that the price of cotton is one day sixpence a pound, and the next day, as a result of the failure of the cotton crop, a shilling a pound. Each pound of the cotton bought at sixpence, and worked up after the rise in value, transfers to the product a value of one shilling. (CI p319)

This is flatly incompatible with the idea that the value transferred to the product by constant capital is predetermined independent of its price. When the price changes, even after the cotton has entered production, so does the value it transfers to the product. Throughout Capital the value of constant capital is represented by the value of the money with which it is purchased and the value of variable capital by the value of the money with which it in turn is purchased. The change in Volume III consists in this: the shilling no longer directly represents the labour time necessary to produce the cotton. The movement of capital can intervene so that the value of the shilling is not equal to the value of the cotton, or to put it another way, the means of production as a result of competition represent a larger or smaller proportion of total socially necessary labour than is directly embodied in them through production.

Abstraction in Volume I does not mean deriving the relations of some special economy but identifying universal characteristics of all economies that produce commodities by means of the commodity labour power. Marx's exchange relations are independent of any particular relations of production, a classical axiomatic procedure originating with Euclid.

Quotations such as the above remain true when the shilling no longer represents the socially necessary labour time required to produce the cotton, but the socially necessary labour time transferred to the purchaser of the cotton through the mediation of circulation.

This minor modification falsifies nothing essential. For Marx it was a tidying-up operation. Scattered throughout Capital are many remarks showing that he considered the value transmitted by inputs was given by the value of the money paid for them:

the average price of labour, i.e. the value of labour power, is determined by the production price of the necessary means of subsistence. If this rises or falls, so does the price of labour. (CIII:1008)

A monopoly price for certain commodities simply transfers a portion of the profit made by the other commodity-producers to the commodities with the monopoly price...If the commodity with the monopoly price enters into the necessary consumption of the labourer, it increases wages and thereby reduces surplus-value (CIII:1001)

and so on. His transformation is neither ambiguous, unfinished, unclear or even difficult. Once adopted all the alleged contradictions and discrepancies in his theory vanish. Both equalities hold; there is only one rate of profit; and it falls as Marx expected and as, in reality, it does.

\section{The death of money, and the dualistic conception of price}

Simultaneist Marxism had to square the circle; to salvage something that looked like value from a system which had excised it. The idea that emerged was that values and prices lived in two parallel worlds. Value, the concealed reality, was measured in hours, and prices, the surface appearance, were measured in gold. ${ }^{13}$ The consequence is what Wolff, Callari and Roberts term 'essentialism' but I believe is more properly termed 'reductionism'; the idea that value is a phenomenon of production and technology, and price is a phenomenon of circulation. From this point of view, production 'embodies' a number of hours in the product independent of, and unaffected by, the relations of circulation. This is its value. Circulation then takes these hours, stashes them in Plato's cave, and exchanges the product with others in ratios determined by the requirement that the necessary proportions of production and consumption should be met. This is its price. Having done this, it furtively exhumes the dead hours and shovels them into the furnace of production before anyone notices.

Many simple things are thus transformed into mysteries. The 'transformation problem' is insoluble because value and price are measured in two different units. There is no causal connection between them and Marx's 'equalities' are reduced to a catechism with no justification other than that the 
master believed them. But these self-inflicted mysteries do not exist in Marx - who is, however, concerned with other much more serious problems which cannot even be formulated in such a framework.

All Marx's distribution relations can be expressed in either money or labour hours as he himself does. ${ }^{14}$ Exploitation means that a labourer who creates a car worth $£ 4000$ from $£ 2000$ of raw materials creates $£ 2000$ of new value and gets paid $£ 1000$. The transformation of price into value does not refer to the fact that this $£ 4000$ represents 4000 hours or that the worker can acquire her or his necessities by working for 1000 hours. It is a quantitative, not a qualitative relation; because of competition, the capitalist may sell the car for $£ 4500$ or $£ 3500$ instead of $£ 4000$. The $£ 4000$ is its value and its price is the $£ 4500$ or $£ 3500$, or as Marx puts it, the first is the value embodied in it and the second the value it realises.

The labour process adds a quantity of value (the value of the money paid for inputs) to a quantity of value (the money-expression of the value added by the labourer) to yield an output value whose money-expression is the sum of the above. Circulation then adds or subtracts a further quantity of value (the surplus-value transferred in competition) yielding the price of the output, itself a quantity of value measured by the money for which this output is sold.

For Marx, money price is a measure of value alongside and in parallel with socially necessary labour time. Value is the unity of these two determinations, not the separate expression of either one of them. We can neither wish away the fact that a given sum of money represents a given quantity of social labour, as neoclassical economics seeks to do, nor the fact that a given quantity of social labour has to be expressed in a given sum of money through the price mechanism, as theories of 'relative price' try to do:

Since labour-time is the intrinsic measure of value, why use another extraneous standard as well? Why is exchange-value transformed into price? Why is the value of all commodities computed in terms of an exclusive commodity, which thus becomes the adequate expression of exchange-value, i.e. money? This was the problem Gray had to solve. But instead of solving it, he assumed that commodities could be directly compared with one another as products of social labour. (Marx 1970:84)

A complete account of a market economy requires both measures, referred to by Marx as the 'extrinsic' and the 'intrinsic' or 'immanent' measures of value; the ratio between them is the exchange value of money ${ }^{15}$, or the amount of labour-time expressed in a given sum of money. ${ }^{16}$

The really difficult task of political economy is to identify the dynamic relation between the two and trace its laws of motion. The simultaneist construction, which assumes this relation to be a pure numéraire, cannot even express this problem, let alone solve it.

\section{Time and money; the indispensable connection}

In a certain sense two quite distinct problems are involved in transforming values into prices. There is a difference between two stages of the life of a commodity: as it emerges from production, with a value equal to the sum of that transferred by the dead and created by the living labour incorporated in it, and as it is transformed in circulation with a price that may now incorporate labour transferred from other producers or alternatively may lose labour to them.

Authors who preserve a simultaneous interpretation are unable to distinguish these two distinct moments of the transformation and are magnetically drawn to the conclusion that either the intrinsic (hours) or extrinsic (money) measure of value is primary and the other a reflection, since for them the same amount of money always represents the same number of hours. Actually the two measures can vary quite independently of each other and a second question is therefore posed: what actually determines the relation between them? This is a discrete, distinct quantitative relation which simultaneism conflates with the first.

Money, unlike labour time, is a dynamic or variable measure because the same quantity of money can represent different amounts of labour time at different times. But as a store of value, it accumulates in the form of its own use value so that changes in its value effect transfers between holders of financial and other assets. This is the material basis of liquidity preference, which requires no special psychological explanation. It has a real impact on capitalist accumulation. If prices are 
rising, its purchasing power is falling - its value is falling. If prices are falling, the value of money is rising and capitalists can make profits in real (value) terms by holding onto it.

The most common and conspicuous phenomenon accompanying commercial crises is a sudden fall in the general level of commodity-prices occurring after a prolonged general rise of prices. A general fall of commodity-prices may be expressed as a rise in the value of money relative to all other commodities, and, on the other hand, a general rise in prices may be defined as a fall in the relative value of money. (Marx 1970:183)

When discussing transformation Marx abstracts from these changes to study transformation in its simplest terms.

A further series of factors have also to be taken into account in our analysis, factors which affect the sizes of $\mathrm{c}, \mathrm{v}$ and $\mathrm{s}$ in a decisive way, which must therefore be briefly mentioned. Firstly, the value of money. This we can take as constant throughout' (CIII:142, emphasis in original).

The value of money is thus, at this stage, not transformed. Bortkiewicz has a different, essentially Ricardian goal: he wants to reduce price to a pure ratio. He therefore introduces a new conception; that money enters the equalisation of the profit rate like any other commodity. But this is not actually possible, because money has a job no other commodity is called on to perform; it must act as the universal equivalent, the medium in which all other commodities express their value. If the price of all other commodities rises, then its value must fall and vice versa. The value of money therefore sums up and recapitulates the entire contradictory movement of accumulation. It is historically concrete.

It cannot attain any arbitrary level; but the adjustment mechanism is dynamic with no equilibrium counterpart. A rising value of money leads to speculative retention of money, that is, hoarding, and the withdrawal of capital from accumulation. In the first stage of slump the resultant reduction in demand accentuates the fall in the price level and the positive feedback leads to further hoarding. But the depreciation of capital brought about by the slowdown in accumulation eventually leads to investment opportunities with a profit rate which exceeds the speculative return on money. When the volume of such investment is sufficient, the movement is reversed and the phase of recovery begins.

The development of this relation requires analysis of the full complexities of the capitalist system, which Marx did not complete: at the very least the credit system, government, and foreign trade. It is thus at one and the same time theoretically much simpler, and practically more complex, than the simultaneists realise. Our first task, therefore, is to liberate it from its simultaneist shell and restore it to its rightful place as the outcome of the process of capitalist reproduction in its entirety. This is not the completion of political economy but only its proper beginning.

\section{MONEY, PRICE AND VALUE}

All post-Bortkiewicz accounts derive the price-value relation from the conditions of production. However the two most essential price-value relations, namely Marx's 'first equality' and the value of money, are exchange relations. This section establishes them for all market prices by analysing exchange.

\section{Exchange at market prices with a constant value of money}

Consider two proprietors who constitute a society with the endowments of table 1 , which introduces a convention used throughout: use-values are italicised and placed in square brackets after the corresponding values thus : 200[25]. One hour of socially necessary labour time is expressed in $£ 1$. The initial unit values of commodities $\mathrm{C} 1$ and $\mathrm{C} 2$ are $£ 8$ and $£ 4$. 


\begin{tabular}{|c|c|c|c|c|}
\hline STOCKS & Commodity 1 & Commodity 2 & Money & Total wealth \\
\hline Capital 1 & $200[25]$ & & $300[£ 300]$ & $500[£ 500]$ \\
\hline Capital 2 & & $80[20]$ & $300[£ 300]$ & $380[£ 380]$ \\
\hline
\end{tabular}

Table 1 Two-party exchange, sale at prices equal to values $p_{1}=£ 8, p_{2}=£ 4$.

Figures given as: Value[Use-value]

Now suppose the proprietors sell all their goods ${ }^{17}$ with a constant value of money at unit prices of $£ 4$ and $£ 9$, as shown in table 2 .

\begin{tabular}{|l|ccrr|}
\hline STOCKS & Commodity 1 & Commodity 2 & Money & \multicolumn{1}{c|}{ Total wealth } \\
\hline Capital 1 & & $180[20]$ & $220[£ 220]$ & $400[£ 400]$ \\
Capital 2 & $100[25]$ & & $380[£ 380]$ & $480[£ 480]$ \\
\hline
\end{tabular}

Table 2 Two-party exchange, all goods sold at prices $p_{1}=£ 4, p_{2}=£ 9$.

This effects a redistribution of value, as shown in figure 1. Exchange cannot create value, but can only change its ownership. Therefore the sum of values in society is the same before as after or, more precisely the sum of values in society is equal to the sum of prices in society - Marx's 'first equality'. This can be expressed in money. The 25 units of $\mathrm{C} 1$ whose value was $£ 200$, for example, are now assessed at $£ 100$; that is $£ 100$ of their value has been transferred to $\mathrm{C} 2$. But total value was $£ 880$ before and remains $£ 880$ afterwards, because what was lost by $\mathrm{C} 1$ was gained by $\mathrm{C} 2$.

Value redis tribution between capitals constant value of money

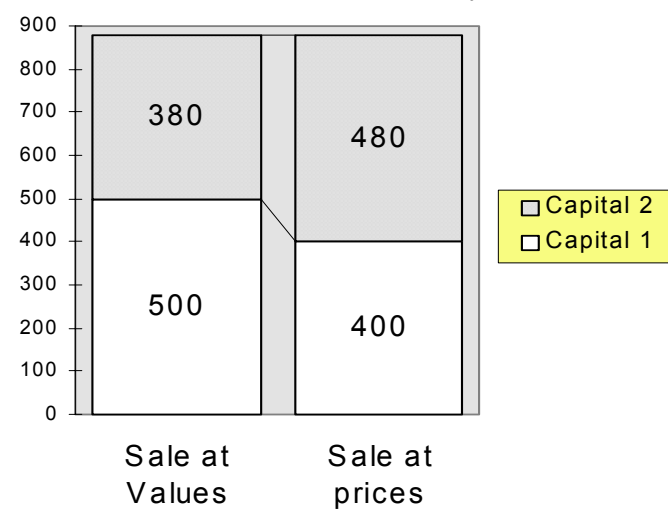

Value redis tribution be twe en commodity stocks, constant value of

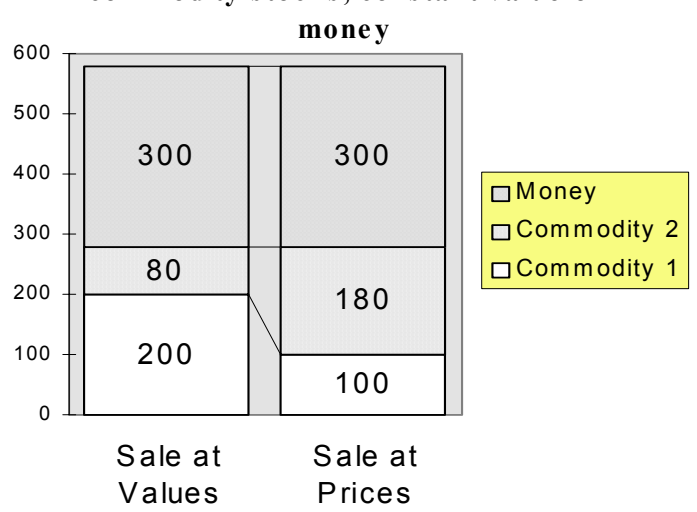

Figure 1 Value redistribution with a constant value of money

\section{Exchange with a variable value of money}

The indescribable confusion surrounding this simple relation arises as follows: if the value of the commodity in which prices are expressed changes, then the sum of prices will also change.

Suppose, for example all money prices double. For simplicity suppose C1 and C2 exchange 'at values' - in the proportion 8:4 - but at twice the money price. Prices are now $£ 16$ and $£ 8$. No special knowledge of value theory is needed, just solid bookkeeping. We price the commodities at the new rates, charge capitalists with their purchases and credit them with their sales.

Table 3 shows the value of each commodity estimated in money at the given prices; and then as before, the use value of the commodity estimated in its natural units.

\begin{tabular}{|l|rrrr|}
\hline STOCKS & Commodity 1 & Commodity 2 & \multicolumn{1}{c|}{ Money } & Total wealth \\
\hline Capital 1 & & $£ 160[20]$ & {$[£ 300-£ 160+£ 400=£ 540]$} & {$[£ 700]$} \\
Capital 2 & $£ 400[25]$ & & {$[£ 300-£ 400+£ 160=£ 60]$} & {$[£ 460]$} \\
\hline
\end{tabular}

Table 3 Two-party exchange, all goods sold at $p_{1}=£ 16, p_{2}=£ 8$

Total wealth in society is now $£ 1160$ instead of $£ 880$; although price ratios have not altered, their money measure has. Everything has inflated in the proportion $880 / 1160=11 / 14$.

In a certain sense this is obvious. If I buy a ton of steel for $£ 1000$, and all prices double, I can sell it for $£ 2000$, an apparent profit of $£ 1000$. But it is equally obvious this expresses no change in the 
underlying real worth of the steel and that a society which confines itself to making profits by raising prices will quickly starve. My speculative gain through this price change must be somebody else's speculative loss - in this case the previous holders of money. Not even the most ardent anti-Marxist could seriously claim otherwise.

This is not altered when society's wealth consists of several commodities that are exchanged between its members as in table 3. No new commodities have made their appearance. How can wealth be created out of nothing? 'Society' has clearly not created an extra $£ 280$; it has moved the goalposts. The 'real worth' of these commodities has to be distinguished from their money measure. This 'real worth' is value. It has to be measured in something external and prior to the act of exchange, for which Marx proposes the socially necessary labour time contained in them. ${ }^{18}$

It is not money that renders the commodities commensurable. Quite the contrary. Because all commodities, as values, are objectified human labour, and therefore in themselves commensurable, their values can be communally measured in one and the same specific commodity, and this commodity can be converted into the common measure of their values, that is into money. Money as a measure of value is the necessary form of appearance of the measure of value which is immanent in commodities, namely labour-time (CI:188)

Thus though $£ 1$ was the money expression of one hour, the new pound expresses $11 / 14$ hour. We can thus resolve the issue by measuring all values in hours. As figure 2 shows, on this basis, redistribution of value without creation of value takes place, exactly as Marx argues; the 'first equality' applies with full force. As before, the extent of the redistribution does not depend on the volume of trade.
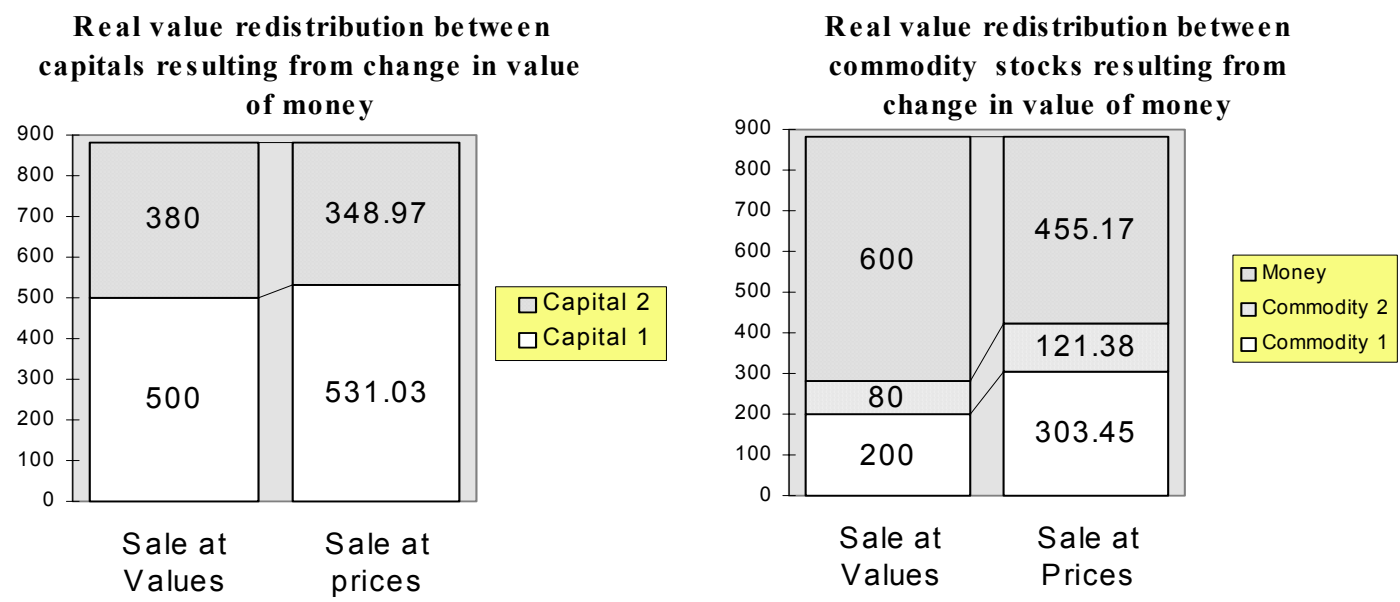

Figure 2 Real value redistribution brought about by a change in the value of money

However this same fact can be expressed in money terms. There are two money measures of value: the money in which commodities were assessed before exchange, and that in which they are assessed now. £1new is worth £old $11 / 14$, just as if there had been a general devaluation - which in fact is what has happened. The variation does not arise from the measurement of value in pounds instead of hours, but from changes in the value of the pound. The confusion between these two different sources of variation is the origin of the incredible muddle surrounding transformation.

Two alternative solutions can now be assessed. The Ricardian answer would be: all prices have doubled, so money has halved its purchasing power. This neglects the fact that money itself is a repository of value. The $£ 600$ held in the economy now represents only 455.17 hours, or £old455.17. It is not a simple numéraire and as Marx points out, the equality of total values and total prices includes the stock of money. The dynamics of the price-value relation rest on this dual nature of money.

A second answer, known as the New Approach, ${ }^{19}$ considers the value of money to be the value of the net product it purchases. Writers of this school have performed a great service in rediscovering the importance of the value of money. However I think they describe a different though important 
quantity, the value-creating capacity of one hour of labour. We need to know what this is but it is not the same as the purchasing power of money. It will only be so in the limiting case where fixed capital is ignored and the value of money is constant; that is, in equilibrium.

\section{Conclusions}

This section has established two essential points. First, in the fully general case of sale at market prices, the total value realised by all commodities in circulation is independent of their market prices; second, this relation assumes only that commodities exchange for money and that labour power enters directly or indirectly into their production.

The correct logical basis has thus been laid to deduce, as Marx did, the relations of the labour process from the exchange relation and the role of the special commodity labour power.

\section{WAGES, PRICE AND PROFIT}

The debate on value is in essence about the origin of profit. If I combine two pieces of bread costing $10 \mathrm{p}$ each and a piece of ham costing 20p, I get a sandwich for which I had to pay 40p. The mystery of capitalist production is that if my labour costs $10 \mathrm{p}$, my boss can sell the sandwich for 60p. Why doesn't competition depress the price of the sandwich to what it costs to make? People can in principle hire labourers themselves and get sandwiches made for 50p. How can the capitalist consistently retrieve more than 50p from selling them?

Proudhon, giving vent to the outrage of a dispossessed artisan class, claimed the employer robs the worker by cheating the laws of supply and demand; selling the sandwich for more than the social cost of its manufacture. Ricardo showed that such a surplus appears even if goods exchange at their 'natural price' when supply and demand balance perfectly. But when the movement of capital unbalances these 'natural proportions', the actual price at which goods sell is not equal to what his theory says they should be. He can draw no conclusions from this and resorts to arguing that the difference is not very big.

Vulgar economics treats capital as an extra commodity. 'Natural price' becomes costs plus a fixed proportion of the money advanced, the price of 'capital'. In effect, this attributes the creative power of capital to its exchange value, with awkward consequences: if exchange value creates value, why bother with factories? Why not just leave money in the fridge and watch it make free lunches?

However our purpose here is not to rehearse the arguments against this idea but to point out that it does not actually overcome the Ricardian dilemma, namely, how can the actual market price deviate from the natural price which theory dictates? Walrasian equilibrium or long-run prices are no better a basis than Ricardian values to talk about disequilibrium behaviour, that is, the real world. Indeed deviations of market prices from equilibrium render the price of 'capital' non-uniform and destroy the basis of the construction. The same objections that brought down Ricardian theory apply with full force to general equilibrium, and its proponents do the same as Ricardo: they wave their hands in the air and say the difference is not very big.

Marx's analysis shows that despite these deviations, there are things which political economy can say. It can show who gains, and who loses, from any price movement and so uncover the common material interest in price movements of a particular type, such as wages, rents, interest rates, exchange rates, taxes, tariffs, foodstuffs, machined goods, and so on. It can thus lay bare the basis of classes and the struggles between them; and it can even discover general laws that govern the rate of profit, the business cycle and accumulation. This does not require sale at any particular set of prices, least of all prices of production, which was only a starting point for commercial profit, mercantile profit, interest, rent, monopoly price, revenues, accumulation, and so on.

We therefore have to demonstrate that if we can find out how much real value a given sum of money represents, then we can interpret the real social content of any set of prices by showing how it has distributed the substance of this value - labour time - between the various classes in society. If we can further show how this allocates real social resources to accumulation, we can moreover uncover the general laws which govern the growth of capitalist society. The attacks on Marx amount to saying that this cannot be done consistently. It can, and Marx did it. 


\section{The sequential principle and chronological time}

Suppose consumption and production take place in a given period, which we shall call period 1, according to the quantities given in table 4 below. L, the value product, is the amount of value added by the labourers and is proportional to the time they work.

\begin{tabular}{|l|cccccccc|}
\hline \multicolumn{1}{|c|}{ FLOWS } & & C1 & C2 & L & & C1 & C2 & Labour Power \\
\hline $\begin{array}{l}\text { Producer P1 } \\
\text { Producer P2 } \\
\text { Labourers }\end{array}$ & $\begin{array}{l}\text { used } \\
\text { used }\end{array}$ & 40 & 10 & 300 & and produced & 50 & & \\
consumed & & 50 & 200 & $\begin{array}{c}\text { and produced } \\
\text { and reproduced }\end{array}$ & & 100 & \\
\hline
\end{tabular}

Table 4 Quantities consumed and produced in period 1

The simultaneist calculation of value proceeds thus; input prices must equal output prices. Assume for now that outputs sell for their values. This gives a system of equalities for these values $\lambda_{1}$ and $\lambda_{2}$ :

$$
\begin{gathered}
50 \lambda_{1}=40 \lambda_{1}+300 \\
100 \lambda_{2}=10 \lambda_{1}+200
\end{gathered}
$$

thus

$\lambda_{1}$ (beginning and end of period 1$)$ : $\quad 30$

$\lambda_{2}$ (beginning and end of period 1): $\quad 5$

5

But this assumes that the inputs $\mathrm{C} 1$ were purchased at prices which have not yet been formed. They must in fact have been purchased at the prices of the previous period, period 0 . These in turn could not have been determined by present conditions, which were not known when they were formed. They are a historical given: in dynamic theory throughout the sciences this is known as an initial condition. Suppose for example they are:

\begin{tabular}{lc}
$\lambda_{1}($ beginning of period 1$):$ & 10 \\
$\lambda_{2}($ beginning of period 1$):$ & 5 \\
\hline
\end{tabular}

The value which these inputs transfer to the outputs in period 1 are given, as we have said, by the value of the money paid for them, namely

\begin{tabular}{lll}
\hline Constant capital 1, period 1 & $40 \lambda_{1}=400$ \\
Constant capital 2, period 1 & $10 \lambda_{1}=100$ & (5) \\
\hline
\end{tabular}

The value added by labour is 300 and 200 respectively, so outputs are worth

\begin{tabular}{lll}
\hline Value of C1 outputs: & $400+300=700$ \\
Value of C2 outputs: & $100+200=300$ & $(6)$ \\
\hline
\end{tabular}

The result is a new unit value for $\mathrm{C} 1$ and $\mathrm{C} 2$, the unit value at the end of period 1 :

\begin{tabular}{ll}
\hline$\lambda_{1}($ end of period 1$):$ & $700 \div 50=14$ \\
$\lambda_{2}($ end of period 1$):$ & $300 \div 100=3$
\end{tabular}

This new unit value is perfectly determinate. It was calculated strictly on the principles of value theory as the sum of dead and living labour, and it cannot be negative unless one of the inputs its negative. The only difference is that it is no longer assumed equal to the value at the end of period 1 . There is thus a complete viable alternative mathematical procedure to simultaneous equations which treats values, just like Marx and unlike Bortkiewicz, as a 'kind of causal chain, in which each link is determined, in its composition and its magnitude, only by the preceding links'

\section{Market price and value}

To extend this to prices suppose the commodities emerging from production with values (7) sell for a price differing from them, let us say

\begin{tabular}{lcl}
\hline$p_{1}($ end of period 1$):$ & 12 & \\
$p_{2}($ end of period 1$):$ & 4 & $(8)$ \\
\hline
\end{tabular}


These are not equilibrium prices. They are the market prices of period 1, in general different from the market prices of period 0 . We do not know where they came from and it is not relevant to our enquiry; they are data, from the economy under study.

For simplicity assume the market price of labour power equals its value. Each seller then realises a quantity of value as follows:

\begin{tabular}{ll}
\hline Price of $\mathrm{C} 1$ outputs & $50 \times 12=600$ \\
Price of $\mathrm{C} 2$ outputs & $100 \times 4=400$ \\
\hline
\end{tabular}

Comparing this with the values embodied in these same products, given by equation (6) shows that 100 units of value have been transferred from the producers of $\mathrm{C} 2$ to the producers of $\mathrm{C} 1$, without changing the total value in society, being 1000 plus the value of labour power (which has not changed). This is a perfectly determinate difference between price and value. Readers may object that it cannot be calculated. Precisely. It is determined by the real world, not the equations. What is important is that we can quantify it, and thus state the necessary relations between it, profit, and surplus value.

In general, circulation effects a transfer of values defined by a transfer vector which in our mathematical writings we call E; thus

$$
\mathrm{M}^{\prime}=\mathrm{C}^{\prime}+\mathrm{E}
$$

where $\mathrm{C}^{\prime}$ is the value of outputs and $\mathrm{M}^{\prime}$ their money price. If the value of money has changed during circulation then we have to be careful to measure this money quantity in old money rather than new; if this is done, whatever market prices prevail the total of $\mathrm{M}^{\prime}$ must equal the total of $\mathrm{C}^{\prime}$ and hence

$$
\Sigma \mathrm{E}=0
$$

\section{Surplus Value}

In period 1 the labourers consumed 50 units of $\mathrm{C} 2$, which they purchased with the wages of this period; these wages were therefore $50 \times \lambda_{2}=50 \times 5=250$ in total, or $1 / 2$ per unit of value product. Variable capital in each sector is therefore

\begin{tabular}{ll}
\hline Variable 1, period 1: & $300 \times 1 / 2=150$ \\
Variable 2, period 1: & $200 \times 1 / 2=100$ \\
\hline
\end{tabular}

Surplus value is the value of sales less the value of consumed capital

$$
\mathrm{S}=\mathrm{C}^{\prime}-(\mathrm{C}+\mathrm{V}) \text {, that is }
$$

Surplus value 1, period 1: $\quad 700-(400+150)=150$

Surplus value 1, period 1: $\quad 300-(100+100)=100$

and total surplus value is 250 . We could of course have derived this directly from L. But expressing it in this way paves the way for a derivation of the relation between profit and surplus value.

\section{Profit}

Profit is the difference between the money price at which outputs are sold and its money costs

\begin{tabular}{lc}
\hline Profit 1 period 1: & $600-(400+150)=50$ \\
Profit 2 period 1: & $400-(100+100)=200$ \\
\hline
\end{tabular}

The sum of profits is 250 , the same as the sum of surplus values. This is an obvious consequence of Marx's 'first equality' and it is completely general, applying to any given set of market prices provided we calculate it in terms of the value represented by each sum of money, and not the sum of money itself: that is, provided we account properly for any changes in the value of money. Profit, money price less costs, is given by the expression

$$
\Pi=\mathrm{M}^{\prime}-\mathrm{C}-\mathrm{V}
$$

But we already know $\mathrm{M}^{\prime}$ is equal to $\mathrm{C}^{\prime}+\mathrm{E}$. Therefore

$$
\begin{gathered}
\Pi=\mathrm{C}^{\prime}+\mathrm{E}-\mathrm{C}-\mathrm{V} \\
=\mathrm{C}+\mathrm{L}+\mathrm{E}-\mathrm{C}-\mathrm{V} \\
=\mathrm{L}-\mathrm{V}+\mathrm{E} \\
=\mathrm{S}+\mathrm{E},
\end{gathered}
$$


that is, profit differs from surplus value by the same transfers of value as differentiate price from value. To be more precise, the difference between profit and surplus value in period 1 is equal to the difference between price and value in period 1 - or indeed in any given period. Over all of society, summing gives the relation

$$
\Sigma \Pi=\Sigma \mathrm{S}+\Sigma \mathrm{E}=\Sigma \mathrm{S}
$$

The sum of profits is equal to the sum of surplus values, or Marx's 'second equality'.

Finally, to foreshadow results of the next section, note the disappearance of a fake distinction 'discovered' by Bortkiewicz; between the value rate of profit and the price rate of profit. The rate of profit is given by the total surplus value divided by the advanced capital. The denominator of this expression is the total money advanced by the capitalist and its numerator is either $\Sigma \mathrm{S}$ or $\Sigma \Pi$ which, as we have just proved, are the same.

\section{The origin of price-value differences in chronological time}

We can now attach a perfectly precise meaning to all quantities in the disputed citations from Marx, provided we take into account their time period. To illustrate the entire movement, we have to know the values with which commodities left production in period 0 ; we have only specified the values with which they entered production in period 1, namely

\begin{tabular}{lc}
\hline$\lambda_{1}($ beginning of period 1$):$ & 10 \\
$\lambda_{2}($ beginning of period 1$):$ & 5
\end{tabular}

However, these values contributed by the inputs of period 1 were the prices with which they left period 0 . Suppose that the values with which they left period 0 were different from these prices, for example

\begin{tabular}{lll}
\hline$\lambda_{1}($ end of period 0$):$ & 8 & $(10)$ \\
$\lambda_{2}($ end of period 0$):$ & 6 & \\
\hline
\end{tabular}

Consider now the 40 units of $\mathrm{C} 1$ entering production as inputs of capital 1 . Although their value at the end of period 0 was $40 \times 8=320$, the price for which they were purchased was $40 \times 10=400$ and this is the value they transferred in period 1 to the outputs of capital 1 , as we have already noted. There is thus a difference between the price and the value of the inputs in period 1 as follows:

\begin{tabular}{|c|cc|}
\hline $\begin{array}{c}\text { Value of commodities } \\
\text { purchased as inputs }\end{array}$ & Value-Price Difference & $\begin{array}{c}\text { Price of commodities } \\
\text { entering production }\end{array}$ \\
\hline $40 \times 8=320$ & 80 & $40 \times 10=400$ \\
$10 \times 8=80$ & 20 & $10 \times 10=100$ \\
\hline
\end{tabular}

Table 5 Price and value of inputs in period 1

This difference, incidentally, is not created out of nothing but is lost to the consumers of $\mathrm{C} 2$, whose price (in period 0) has risen.

We can now match these various value-price differences to Marx's own periodisation of the labour process, but with a vital clarification: we distinguish what happens in period 0 from what happens in period 1:

\begin{tabular}{|c|c|c|c|c|c|c|c|c|c|}
\hline \multirow{3}{*}{$\begin{array}{l}\text { Phase } \\
\text { of the } \\
\text { circuit }\end{array}$} & \multicolumn{2}{|c|}{ Period 0} & \multicolumn{7}{|c|}{ Period 1} \\
\hline & $\overline{\mathbf{C}^{\prime}}$ & $\overline{M^{\prime}}$ & & C & & $\mathbf{P}$ & $\mathbf{C}^{\prime}$ & & $\mathbf{M}^{\prime}$ \\
\hline & $\begin{array}{l}\text { Value of } \\
\text { commodities } \\
\text { purchased } \\
\text { as inputs }\end{array}$ & $\begin{array}{c}\text { Value-Price } \\
\text { Difference } \\
\text { (Period 0) }\end{array}$ & C & $\mathbf{V}$ & $\mathbf{L}$ & $\mathbf{P}$ & $\mathbf{C}^{\prime}$ & $\mathbf{M}^{\prime}$ & $\begin{array}{c}\text { Value-Price } \\
\text { Difference } \\
\text { (period 1) }\end{array}$ \\
\hline C1 & 320 & 80 & 400 & 150 & 300 & 550 & 700 & 600 & -100 \\
\hline $\mathrm{C} 2$ & 80 & 20 & 100 & 100 & 200 & 200 & 300 & 400 & +100 \\
\hline
\end{tabular}

Table 6 Summary of value-price differences in period 1 for both inputs and outputs 
There are thus not one but two perfectly distinct sets of price-value differences, as Marx points out in his famous allegedly 'confused' passage (CIII:309):

We have already seen that the divergence of price of production from value arises for the following reasons: (1) because the average profit is added to the cost price of a commodity, rather than the surplus-value contained in it; (2) because the price of production of a commodity that diverges in this way from its value enters as an element into the cost-price of other commodities, which means that a divergence from the value of the means of production consumed may already be contained in the cost price, quite apart from the divergence that may arise for the commodity itself from the difference between average profit and surplus value...

These occur at two different points in time. The divergence 'already contained in the cost-price' is the first value-price difference, which arose in period 0 , and the second is the difference between the surplus value and profit in period 1 .

\section{RELATIVE SURPLUS VALUE}

For all results so far obtained, equilibrium can be treated as a special case: when technical change is slow and price adjustment is rapid, it can be claimed that the deviations from equilibrium are shortlived and irrelevant.

This is justified by a property of iterative solutions known as convergence. If the technology remains constant, and if the rate of profit is equal, then (and only then) iterated values and prices converge to the same magnitudes as the simultaneous solution.

Many authors react to the sequential treatment as if it were merely as a means of deriving a simultaneous solution. The proponents of iterative solutions are to some extent to blame. They have focused on this property, as if the task were to provide a better explanation of equilibrium magnitudes than the simultaneists.

Unfortunately convergence is not a property of capitalism. It ceases to apply as soon as technical change is introduced. In short it only applies only to absolute surplus value, in effect the concern of the Sraffian problematic, all parameters remaining constant except the real wage. For relative surplus value the property no longer holds. Iterations cease to converge and have to be interpreted differently, as a representation of real prices in and of themselves.

But relative surplus value is not optional. It is a distinct phase of capitalism, beginning with the industrial revolution, when capital competes with capital by harnessing technology and as a whole subsumes the universal creative powers of human labour to the production of profit for the sake of profit. Therein lies the practical failure of apologetics; distilling the market's 'pure' form has vapourised its most potent ingredient.

Instead of proving that prices converge theoretically, political economy has to ask when they do not converge actually. Under these circumstances, the simultaneous solution is not only theoretically invalid but practically unattainable. Nonlinear dynamics reveals that for most periodic behaviour the theoretical equilibrium does not even represent an average or possible limit point. If a moving economy behaves in this way, the battery of analytical tools associated with equilibrium are irrelevant, inoperative, and false.

The conditions for capitalism to attain equilibrium are that it should cease do what makes it capitalism; namely it should cease to invest in technical advance. The tendency of modern times is quite the reverse; it has turned even technical advance into intellectual property, making communication a crime for the first time since Metternich.

It follows that if technical progress leads to a clear qualitative difference between predictions made by simultaneous and by sequential systems, then there is no remaining foundation for simultaneism except empirical accuracy, on which terrain it has not fared well. This is the concern of our final section. 


\section{What is capital?}

Under capitalism the means of production are commodities. They produce commodities, they are purchased as commodities but above all exist as commodities. While producing, they partake of the commodity's dual nature as a contradictory unity of value and use value. They transmit value to their products not because they once had value but because they still do. Their ability to mobilise living labour is not derived from their individual qualities but their relation to all other commodities that discharge the same function, with which they form a unified social whole through the mediation of their common market price.

If the amount of labour-time socially necessary for the production of any commodity alters - and a given weight of cotton represents more labour after a bad harvest than after a good one - this reacts back on all the old commodities of the same type, because they are only individuals of the same species. (CI:318)

We have already seen that the vulgar idea of capital as pure money leads to absurdity. Because it does not ask how much real value this money represents, it cannot distinguish accumulation from changes in the value of money. Simultaneist theories, from which money is formally absent, generally come down on the other side of the coin when formulated rigorously, reducing capital to a technical entity, a congeries of use values engaged in production.

This reduces to one of three proposals. Either capital does not exist as stocks at all (Bortkiewicz); or the commodities which function as capital are different from those which do not (Walras); or commodities of different ages constitute different use values (von Neumann and Sraffa).

But all commodities exist as stocks, even if only as work in progress. One needs only ask what a Bortkiewicz system looks like if the period of production is half a year instead of a year, and stocks miraculously appear. Moreover all commodities function as capital, because money must be advanced to employ them in production. And finally, all commodities of the same type form part of a common stock. If house prices fall, then the price of all houses falls, including both old and new. What falls is the price of a house, a thing for living in, not the price of a new house, a new thing for living in. This changes only if it becomes a ruin, a thing no-one lives in.

It therefore makes a difference how much was paid for them. A computer that cost $£ 3000$ three years ago does not play the same role in the self-expansion of capital as a computer which is technically the same but was purchased today for $£ 1000$. The $£ 3000$ has been advanced. Repayments reduce current profits and advanced money figures in the denominator of the profit rate. The main premise of the surplus approach school - that technology and the real wage determine the profit rate independent of circulation - is false, since we can construct two economies with identical technology, an identical real wage, but with different historical costs and therefore different profit rates.

Moreover because there is a stock of identical use values purchased at different prices, the market price of this use value forms as a social average of all historically-existing computers and not just as a social average of the most recently-produced. New technology, therefore, does not reduce the value of constant capital immediately to the cheapest theoretically available but to an intermediate value, depending how many cheaper computers exist compared with their more expensive equivalents. In the process the technology haves drain the technology have-nots of their value, their history, their culture, of all that money can buy, the accumulated living of their people. This we call progress.

It follows that Marx's apparently naïve approach to capital accumulation is more rigorous and closer to capitalist reality than sophisticated critics would have it. Consider his most contentious construct: the tendency of the rate of profit to fall. This has probably been singled out for more ridicule than any other idea. Academic economics accuses him of an almost trivial mistake: he failed to realise that constant capital could get cheaper. If technical progress makes constant capital cheaper, then organic compositions will not increase and the denominator of the rate of profit will shrink. The profit rate can only fall if real wages rise. A mathematically watertight theorem due to N. Okishio (1961) conclusively proves this in the simultaneist framework.

Marx's 'naïve' analysis can be presented in a simplified way as follows: suppose in a given period the capitalists advance, say $£ 1000$ in production, $£ 500$ on wages, and produce $£ 2000$ worth of goods. Assuming they plough back the advanced capital, they have now $£ 500$ in profit. If they invest any portion of this, no matter how small, the advanced capital must get bigger. Therefore they can only 
increase the profit rate if they pay their workers less - to which there is an absolute limit - or disinvest in value terms, that is, stop accumulating.

This is a deduction from the rate of profit formula

$$
r=\frac{\mathrm{S}}{\mathrm{K}}
$$

where $\mathrm{K}$ is accumulated capital, which, we have just seen, is the same in value as in price terms if the value of money stays constant:

In each period, a given amount of new surplus value $\mathrm{S}$ is available either for capitalist consumption or investment. $\mathrm{K}$ grows if any part of $\mathrm{S}$ is invested and shrinks only if the capitalists consume part of $\mathrm{K}$, that is, if they stop accumulating as happens in a slump. This argument makes no special assumptions about the structure of technology at all. It simply says that unless the capitalists spend all their profits on themselves, their capital must increase.

Under Okishio's own assumptions, in most plausible cases the simultaneist construction predicts a rising profit rate, while the sequential construction predicts a falling rate. The first such example was given by Kliman (1988) and a similar example developed independently by myself in $1992 .^{20}$ In Freeman (1995) a complete general refutation of the Okishio theorem is given which establishes that Marx's 'naïve' formula above for the rate of profit is rigorous and the conclusions drawn from it fully justified. This proof is presented for the most general case of all, which is when fixed capital is treated consistently with circulating capital by reducing the period of production, in any case an accounting fiction, to zero. Space does not permit repetition here, but a flavour of the proof can be given in a simple example based on a single commodity which abstracts from fixed capital.

\section{Falling profit rates with rising productivity of labour and a constant real wage}

In order to present the matter in the form which most clearly shows the difference between the two calculations, we consider a society in which

1) the real wage and the use of labour remains constant

2) productivity rises in real terms, that is, output rises steadily

3) the physical surplus is all reinvested

This sets aside all complications that arise if the physical surplus is not wholly reinvested or wholly sold, although as I have shown elsewhere, these complications do not falsify the argument. Assume technical innovation as follows: in each period, society produces enough means of production to expand its stock in the next period by $10 \%$ without employing any more labourers. To simplify the matter further assume this is also the wage good, take the period of reproduction to be that in which the commodity is completely turned over, and assume variable capital is turned over in the same period; for example, that wages are advanced annually. ${ }^{21}$

Suppose capital uses 1500 units of a good C and 300 labour-hours during a year. Suppose labourers consume $1 / 2$ unit of $C$ for each hour they work and that the initial unit price of $C$ is $£ 1$, its equilibrium value with this technology. Assume the value of money to be $£ 1$ per hour. Following our assumptions, in the first period 1800 units of $\mathrm{C}$ are produced. Labourers create $£ 300$ of new value so that the new unit value (= price) is $£ 1$. Reproduction in the first period is then given by the following table

\begin{tabular}{|l|ccccc|}
\hline \multicolumn{1}{|c}{ FLOWS } & C & V & & C & Labour Power \\
\hline Capitalists & $1500[1500]$ & $150[300]$ & produces & $1800[1800]$ & \\
Labourers & $150[150]$ & & reproduce & & $150[300]$ \\
\hline
\end{tabular}

Table 7 Expanded reproduction with technical change, period 1

The simultaneous construction proceeds as follows: let the price of $\mathrm{C}$ be $p$ and the rate of profit $r$. Then in the first period

$$
(1500 p+300 \times 0.5 p)(1+r)=1800 p
$$

Whatever the numéraire the rate of profit is clearly given by

$$
r=\frac{1800-1500-150}{1500+150}=\frac{150}{1650}=9.09 \%
$$

At the end of this period, a new technique becomes available which, with the same number of labourers, employs the unconsumed 1650 units of $C$ to produce a further surplus of 165 , that is a total 
output of $1650+150+165=1965$. Following the same assumptions, physical production in the next period is given by the following table (in which the sequential values have yet to be calculated):

\begin{tabular}{|l|ccccc|}
\hline \multicolumn{1}{|c}{ FLOWS } & $\mathbf{C}$ & $\mathbf{V}$ & & $\mathbf{C}^{\prime}$ & Labour Power \\
\hline $\begin{array}{l}\text { Capitalists } \\
\text { Labourers }\end{array}$ & {$[1650]$} & {$[300]$} & $\begin{array}{c}\text { produces } \\
\text { reproduce }\end{array}$ & {$[1965]$} & {$[300]$} \\
\hline
\end{tabular}

Table 8 Expanded reproduction with technical change, period 2

In the second period the rate of profit is

$$
r=\frac{1965-1650-150}{1650+150}=\frac{165}{1800}=9.17 \%
$$

and if productivity continues to rise in the same way, so will the rate of profit. This is because, although the quantity of $\mathrm{C}$ (the 'technical composition' of capital) is rising relative to the quantity of $\mathrm{V}$, rising productivity, according to this calculation, cheapens the elements of $\mathrm{C}$ fast enough to outpace this change. Without a numéraire the surplus approach technique does not tell us the new unit price, but we can illustrate the point by calculating the new simultaneous unit value, which for one productive sector with a constant value of money is equal to its price. This is given by

giving

$$
1965 \lambda=1650 \lambda+300
$$

The 1650 units of $\mathrm{C}$ devalue to

$$
\lambda=\frac{300}{1965-1650}=0.95
$$

$$
\frac{300}{1965-1650} \times 1650=1571.43
$$

Wages devalue to

$$
\frac{300}{1965-1650} \times 150=142.86
$$

so the added value of 300 yields a surplus of $300-142.86=157.14$. Dividing by advanced capital (

The error in this calculation is as follows: when the capitalists buy their 1650 units of $C$ they cannot buy it at the new, cheaper price of $£ 0.95$ because it has not yet been produced at this price. In the second period they purchase their inputs at the old output price of $£ 1$, paying $£ 1650_{\mathrm{C}}$ and $£ 150_{\mathrm{V}}$. The value of their outputs is $£ 1650_{\mathrm{C}}$ plus the $£ 300$ added by the workers, totalling $£ 1950$. Profits are the difference between this and costs, that is

$$
\mathrm{S}=£ 1950-\left(£ 1650_{\mathrm{C}}+£ 150_{\mathrm{V}}\right)=£ 150
$$

Dividing by the advanced capital of $£ 1650_{\mathrm{C}}+£ 150_{\mathrm{V}}=£ 1800$ gives a profit rate

$$
r=\frac{150}{1650}=8.33 \%
$$

and the new unit value of the outputs is given by

$$
\frac{\text { Total value of period } 1 \text { outputs }}{\text { Total volume of period } 1 \text { outputs }}=\frac{1650_{\mathrm{V}}+300_{\mathrm{L}}}{1955}=\frac{1950}{1955}=0.9974 \text { to four s.f. }
$$

In the next period the same procedure can be repeated and it is found that the simultaneous rate steadily rises while the sequential rate steadily falls.

This simplified example is not to be taken as an attempt to model the real process of expanded reproduction which is immensely more complicated. To draw attention to just one limitation: to purchase the 165 units of physical surplus the capitalists will actually have to spend more than the profit they have earned, which they would have to do by borrowing. It has been chosen in order to show the non-mathematical reader how it can be that the two methods produce decisively different results.

\section{Conclusion: linear production models in perspective}

The debate that followed Sraffa's Production of Commodities by Means of Commodities, no less than Okishio's justly-celebrated theorem took the peculiar form of a discussion between rival interpretations of the same equations. This may have contributed to the acrimony. I think the record may eventually show that it finally established the limits of what can be done with such systems. This testing to destruction is something official economics could not have done, and is perhaps in itself an achievement. I believe the new, emerging work shows that it need not be repeated. This work does 
not offer yet another interpretation of the same results, but different results. The terrain on which to test them is therefore a more familiar one for science; it is time to get back to verifying theory by analysing reality.

The old debate equips us less well to rid ourselves of a conceptual legacy which, as Marx says, 'weighs on the brains of the living'. It will prove justified, in my view, if it enables all concerned to clear their balance sheets for a new start on unfinished business. My hope is that this article will help make clearer what is to be gained from doing so.

\section{NOTES}

1 The 'New Approach' or 'New Solution' to the transformation problem is dealt with separately later in this article.

2 Space does not let us assess the work of R.M.Goodwin and his associates, but in any discussion of non-equilibrium Marxism their distinctive contribution cannot go unmentioned. See particularly Goodwin, Kruger and Vercelli (1984)

3 See Walker's 1988 survey or more recently, for example, Lapavitzas (1994), Kristiansen (1994), Cockshott and Cotrell (1994).

4 Bortkiewicz (1952:23-24). I am indebted to Michele Naples for pointing out this passage.

5 These propositions are formally identical. The fact that we live in an alienated society is mathematically equivalent to the proposition it cannot consciously realise the objectives it sets. Only those who control their destinies can predict their futures.

6 The best-known being Kalecki, although Keynes himself was perfectly aware of the inadequacy of the equilibrium construction. Both traditions are actively developed and extended by the work of the Post-Keynesians. For a general survey see Arestis (1994) or Eichner(1979).

7 As Farjoun (1984) points out, this is a serious defect in the Surplus Approach school's analysis of joint production as well as von Neumann's seminal article, both of which require unsold products to be treated as 'waste' and disposed of at a zero price.

8 Consider for example the universal creed that in Volume I Marx either assumed the organic composition of capital to be constant, or describes a precapitalist stage of history. Both are complete mythology. Volume I abounds with examples taken from the capitalism of Marx's day with wildly different organic compositions. What is meant is 'We can only interpret Volume I under these assumptions; therefore Marx must have assumed it.'

9 This is discussed at greater length in Freeman (1995a)

10 Rodriguez and Ramos, in a forthcoming work (Carchedi and Freeman 1995) were the first to draw attention to this point.

11 In the Theories of Surplus Value Marx uses 'cost-price' in place of what he later termed 'price of production'. The English translation, although unambiguous, would be better rendered 'Thus a portion of the price different from value enters into (geht ein) the commodity'.

12 'The reader should note that we are not speaking here of the wages or value that the worker receives for (e.g.) a day's labour, but of the value of the commodity in which his day of labour is objectified. At this stage of our presentation the category of wages does not exist at all.' (CI:135)

13 This was not the conception of Bortkiewicz, who is more intellectually honest than many of his followers. He presents the predecessor of this idea - that values and prices are determined by two completely separate and independent systems, both however measured in money.

14 I am indebted to Adolfo Rodríguez for many long and fruitful discussions on the issues covered in this section. He is of course not responsible for the explanation given here or any errors in it.

15 Rodríguez (1995) systematically distinguishes the 'value of money' being the value embodied in the commodity serving as money through production, and the 'exchange value of money', the concept discussed above. There is some evidence that Marx drew this distinction as his writing progressed but in many places he uses the two terms interchangeably. We use 'value of money' always to mean its 'exchange value' in the above sense unless stated otherwise.

16 Marx repeatedly asserts that money is the standard of price and value. His distinction is between measure and standard: 'With English writers the confusion over measure of value and standard of price ('standard of value') is indescribable. Their functions, and therefore their names, are 
constantly interchanged.' (CI:98) As a standard, in my piggy bank, the 1980 pennies and the 1990 pennies count as equal. As a measure, a penny in 1980 could buy a lot more.

17 Note that the redistribution of value is independent of the volume of trade.

18 A neoclassical adversary may argue that whilst there has to be a concept of value, it should not be labour time. In which case we await the alternative since what we show here is that it is not provided by long-run equilibrium price.

19 See for example Duménil (1980), Foley (1982) and Lipietz (1982).

20 As this was going to press I was informed that Eduardo Maldonado-Filho (1994) presents very similar ideas developed as early as 1986.

21 The argument is presented assuming wages are paid at the beginning of production. The conclusions are the same if they are paid at the end.

\section{ACKNOWLEDGEMENTS}

I am indebted to Mino Carchedi, Werner de Haan, Andrew Kliman, Ted McGlone, Alejandro Ramos, Bruce Roberts, Adolfo Rodríguez, Alfredo Saad-Filho, Michele Naples and Paolo Giussani for the discussions, comments and ideas which made this article possible and to Gérard Duménil for his helpful comments. These authors do not necessarily in whole or part share the views expressed here and responsibility for them is mine alone.

\section{REFERENCES}

References to Capital are all abbreviated as follows:

CI: Marx, K. (1976a), Capital: A critique of political economy. Volume I. London: Penguin CII: _ (1978), Capital: A critique of political economy. Volume II. London: Penguin

CIII:__ (1981), Capital: A critique of political economy. Volume III. London: Penguin

Arestis, P. (1992),The Post-Keynesian Approach to Economics. Aldershot and Vermont: Elgar.

Bortkiewicz, L von. (1952), 'Value and Price in the Marxian System'(part I), in International Economic Papers, 1952(2), 5-60.

. (1984), 'On the Correction of Marx's Fundamental Theoretical Construction in the Third Volume of Capital', in Sweezy (1984),

Brunhoff, Suzanne de. (1976), Marx on Money. New York: Urizen Books.

Carchedi, Guglielmo. (1984), 'The Logic of Prices as Values', Economy and Society Vol 13 No 4. . (1991),Frontiers of Political Economy, Verso, London.

Clower, R.W. (1967), 'A reconsideration of the microfoundations of monetary theory, ' Western Economic Journal, Vol. 6, pp 1-9.

Cockshott and Cotrell (1994). 'Does Marx need to transform?' paper presented to the 1994 centenary conference, Bergamo, December 1994.

Dmitriev, V. K. (1974), Economic Essays on Value, Competition and Utility (ed. D. M. Nuti) Cambridge: Cambridge University Press.

Dumenil, Gérard. (1980), De la Valeur aux Prix de Production. Une Réinterprétation de la Transformation, Paris: Economica

Eichner, Alfred S. (1979), A Guide to Post-Keynesian Economics. New York: M.E. Sharpe.

Elson, Diane (1979) 'The value theory of labour' in Elson, D (ed) Value: the representation of labour in capitalism (Essays on Value), London: CSE books.

Farjoun, Emmanuel. (1984), 'The production of commodities by means of what?' in Mandel and Freeman (1984).

Foley, Duncan. (1982), 'The Value of Money, the Value of Labour Power and the Marxian Transformation Problem', Review of Radical Political Economics, 14(2).

Freeman, A. (1995) 'Price, value and profit: a continuous, general formalisation' in Freeman, A. and Carchedi, G (1995). 
Freeman, A. and Carchedi, G. (1995) (eds) Marx and non-equilibrium economics, London: Elgar.

Gattei, Giorgio. (1982), 'Les Chaires "Ratées" de Ladislaus von Bortkiewicz', Revue Européenne des Sciences Sociales, Volume 20 No. 62.

Giussani, Paolo. (1991), ‘The Determination of Prices of Production', International Journal of Political Economy, Vol 21, Winter (1991-1992), pp67-87.

Goodwin, R. M., Kruger, M. and Vercelli, A. (eds.) (1984). Nonlinear models of fluctuating growth, an International symposium. Lecture Notes in Mathematical Systems 228, Berlin and New York: Springer-Verlag.

Harcourt, G C. (1972), Some Cambridge Controversies in the Theory of Capital. Cambridge: Cambridge University Press.

Jaffé, W. (ed.). (1965), Correspondence of Léon Walras and related papers. Amsterdam: North Holland Publishing Company.

Kliman, A, 1988. 'The Profit Rate Under Continuous Technological Change', Review of Radical Political Economics, 20(2\&3): pp283-289.

Kliman, A. and McGlone, T. (1988), 'The Transformation non-Problem and the non-Transformation Problem', Capital and Class, 35, Summer, pp56-83.

Kristiansen, D. (1994) The role of demand in Marx's theory of Crisis, unpublished paper presented to the EEA, Boston, March 1994

Lapavitzas, C. (1994). The Classical adjustment mechanism of international balances: the relevance of the labour theory of value. CSE conference paper 1994.

Lipietz, A. (1982), 'The so-called “Transformation Problem” Revisited', Journal of Economic Theory, 26 (1), January, pp59-88.

Komorzynsky J. V. (1897), 'Der dritte Band von Carl Marx "Das Capital”: eine Kritische Abhandlung über die Arbeitswerttheorie und die Socialistische Lehre vom Capitalsertrage', Zeitschrift für Volkswirtschaft, Socialpolitik und Verwaltung, 6:2.

Maldonado-Filho, E. (1994), 'Release and Tying up of Productive Capital and the "Transformation Problem", URPE conference at the ASSA, fall 1994.

Mandel, E. and Freeman, A. (1984), Ricardo, Marx and Sraffa, the Langston Memorial Volume. London: Verso.

Morishima and Catephores. (1978), 'The Transformation Problem: a Markov Process', in Morishima and Catephores. Value, Exploitation and Growth, McGraw Hill, London.

Moseley, Fred. (1993), 'Marx's Logical Method and the "Transformation Problem"”, in Moseley (ed.) Marx's Method in Capital: a re-examination. Atlantic Highlands, N.J.: Humanities..

Marx, K. (1935), The Poverty of Philosophy. Moscow: Progress Publishers. . (1969), Theories of Surplus Value, Part III. London: Lawrence and Wishart. . (1970), A Contribution to the Critique of Political Economy. Moscow: Progress.

Naples, Michele I. (1989), 'A Radical Economic Revision of the Transformation Problem', Review of Radical Political Economics, 21 (1-2), pp137-158.

'Time, Money, Equilibrium and the Labour Theory of Value' in Freeman and Carchedi (1995)

Neumann, John von. (1937), ‘A Model of General Economic Equilibrium', Review of Economic Studies (1945), pp1-9.

Okishio, N. (1961), 'Technical Changes and the Rate of Profit', Kobe University Economic Review 7. pp 86-99.

. (1972), 'On Marx’s Production Prices’, Keizaigaku Kenkyu, 19.

Pala, Gianfranco. (1982), 'Forme di Valore, Denaro, Prezzi non-concorrenziali', Note Economiche No. 1, Siena: Monte dei Paschi di Siena.

Panizza R. (1981), 'Metodo iterativo e problema marxiano della trasformazione', in Panizza R. e Vicarelli S. (eds.), Valori e prezzi nella teoria di Marx. Sulla validità analitica delle categorie marxiane, Torino: Einaudi.

Ramos, Alejandro and Rodriguez-Herrera. (1993), 'The transformation of values into prices of production, luxury articles and commercial capital', Plusvalore, No. 13, Milano.

. (1995), 'The transformation of values into prices of production: a different reading of Marx's text' in Freeman and Carchedi (1995).

Rodriguez, Adolfo. (1995), 'Money, the postulates of invariance and the transformation of Marx into Ricardo', in Freeman and Carchedi (1995). 
Shaikh, A. (1977), 'Marx's Theory of Value and the "Transformation Problem"”, in Hunt and Schwartz (1977)

. (1984), 'The Transformation from Marx to Sraffa', in Mandel and Freeman (1984).

Shibata K. (1933), 'The Meaning of the Theory of Value in Theoretical Economics', Kyoto University Economic Review, 8(2), 49-68.

Sweezy, P. (1962). The Theory of Capitalist Development, London: Dennis Dobson.

Tugan Baranowsky M. (1905), Theoretische Grundlagen des Marxismus, Duncker \& Humbolt, Leipzig.

Walker, Richard, 'The Dynamics of Value, Price and Profit', Capital and Class 35:146-181.

Walras, L. (1984), Éléments d'Économie politique pure, Translated by Jaffé as Elements of Pure Economics or the Theory of Social Wealth, London:George Allen and Unwin (1954) and Philadelphia, Orion Editions (1984).

Wolff, R. D., Roberts, B. and Callari, A. (1982), 'Marx’s (not Ricardo's) “Transformation Problem”: A Radical Reconceptualization, ' History of Political Economy, Vol 14 No. 4., pp 564-582. 